\title{
Difficulties and opportunities when teaching about technological systems in K-12.
}

\section{Dr. Lena B. Gumaelius, KTH Royal Institute of Technology, Stockholm, Sweden}

Dr Lena Gumaelius has a background as a researcher in Biotechnology, in which field she still teaches undergraduate students at KTH. (Lena got her Master of Science in chemistry 1993 and her PhD in Environmental Microbiology in 2001.)

In parallel with her research, she worked for several years with development of experiments for students at House of Science. In 2006 Lena became the director of House of Science, which she remained until 2012. House of Science is a university based Science centre with about 40000 visitors were the goal is to stimulate high school students' interest for the natural sciences, math and technology. During these years Lena developed her pedagogical skills and competence in the pedagogic field and besides leading the activities she organised pedagogical training for teachers, pupils and university students.

Since 2011 Lena is head of the new Department of Learning at the School of Education and Communication in Engineering Sciences (ECE), KTH. Lena is responsible for building up a new strong research environment in engineering and technology education, K-12 to university level.

\section{Dr. Per G. Norström, KTH Royal Institute of Technology}

Per Norström is a lecturer in technology and engineering education at the Royal Institute of Technology (KTH) in Stockholm, Sweden. His research interests include analytical philosophy of technology and its use in engineering education. 


\title{
Difficulties and opportunities when teaching about socio-technical systems in $\mathrm{K}-12$
}

\begin{abstract}
Socio-technical systems are studied in compulsory school (pupils aged 7-16) in Sweden. The purpose is to increase pupils' understanding of how technology and society affect one another by highlighting the interaction between technological artefacts, humans, institutions, and society at large. Many teachers find this subject difficult to teach, and therefore avoid it. To rectify this, a course module about socio-technical systems for teachers was instigated at KTH Royal Institute of Technology in Stockholm. This study was conducted during that course, and shows that teachers are affected by their educational backgrounds in their understanding of the systems; those who are trained in social sciences prioritize different aspects of the systems in their teaching than do those who have started out in the natural sciences. It also shows that the formulation of learning objectives in this area is very difficult for most teachers and few students include goals that relate to more general knowledge in areas such as genderrelated issues, historical aspects or environmental issues. Few of the students showed the ability to create a varied learning environment; searching information on the Internet and writing reports dominate the students' suggestions. Understanding of socio-technical systems has the potential to bridge the gap between engineering and various aspects of society in education. It is therefore an essential part of technological literacy, and teacher training in the area should be improved.
\end{abstract}

\section{Introduction}

In Sweden, technology is a mandatory subject for all pupils in compulsory school (age 7-16). It was introduced in the national curriculum of $1980 .{ }^{1}$ In the current curriculum ${ }^{2}$ it is described as an interdisciplinary subject, including content related to engineering science, applied natural science and the history and sociology of technology. Unlike technology subjects in many other countries, it does not have a strong focus on computers and not on crafts. Crafts are practiced in a separate subject.

In the description of the technology subject's core content, one of the areas listed is 'technical systems' which is listed under the heading 'Technology, man, society and the environment'.

According to the teacher guidelines to the curriculum, this is intended to provide a context for the technological knowledge, to connect engineering and society. ${ }^{3}$ In this sense, the technology subject's 'technical systems' is reminiscent primarily of the large technical systems or socio-technical systems as studied in the STS (Science and technology studies) domain, but also of systems in a more engineering-related sense where the main foci are individual components - material objects - their interdependencies and interactions. The socio-technical systems include a technical core of installations, machinery and other technical artefacts, but also human users and operators as well as laws, rules, regulations and traditions. ${ }^{4,5}$ Interpreted this way, the systems could serve to connect the technology subject to other school subjects. When emphasizing the social and economic aspects, it can be closely connected to civics and geography. If on the other hand the technical core is studied, individual components and processes can be explained in relation to concepts from physics, chemistry, and biology. A conscious inclusion of technical and socio-technical systems in the technology subject can serve to emphasize the role of technology and engineering in human 
societies and for the environment. Thereby it can also show how our dependency on large infra systems have shaped society, affected the environment, and made us vulnerable to accidents and malfunction that occur far away. ${ }^{7,8}$

In many Swedish schools, the study of technical systems is lacking or the quality in teaching

is low. ${ }^{9}, 10,11$ A multitude of reasons for this has been suggested, most importantly the lack of technology teachers with adequate training. In Sweden, most teachers who teach technology are educated in the natural sciences, and has little or no training in technology or engineering. This has led to a technology education that deals with individual artefacts rather than systems, and these artefacts tend to be studied and analysed using methods, tools and criteria from the natural sciences rather than the engineering sciences. ${ }^{10}$

Through a project called 'Boost for teachers' (Lärarlyftet), the Royal Institute of Technology (KTH) in Stockholm has received government funding for professional development courses for teachers in compulsory school who teach technology without having proper education. In a course of 45 ECTS credits (corresponding to 30 weeks of full-time studies), a module of 7.5 ECTS credits (corresponding to five weeks of full-time studies) was dedicated to the study of socio-technical systems and how to include them in technology education for 13-16 year old pupils.

During the course, the students studied STS literature on socio-technical systems, articles about educational aspects of the systems, and also the systems in themselves. The course participants visited various installations such as sewage plants, a functioning and a closeddown nuclear power-plant, a robotics lab and a car factory. The students also had to design a series of lessons centred on a large technological system intended to be used in compulsory school, where they had to describe learning objectives, teaching activities, assessment, etc. The purpose of this study is to describe how technology teachers, who have participated in a course about socio-technical systems, deals with the task of teaching about technological systems, shown through their self-designed teaching activities.

\section{The participants and the course}

The informants of this study all participated in a professional development course for teachers who taught technology without having adequate education. Before taking the module about socio-technical systems, they had studied 30 ECTS credits (corresponding to 20 weeks of full time studies) in technology education, divided into four modules of 7.5 credits each: general technology education studies, product development, electrical engineering, and the history of technology. Two thirds through the course, they were better educated than a majority of Swedish technology teachers. Most of them were originally educated as science teachers, but two came from a crafts background and two from the social sciences.

During the course, each of the students was assigned one of four systems or system types: sewage systems, nuclear power plants, car manufacturing, and the Internet. Each of these corresponded to a system or system type that was studied during the course through literature and field trips. The students' task was to design a sequence of teaching and learning activities intended to teach their own pupils about the system or system type in question. The educational design and pedagogical choices were to be analysed and motivated using literature on socio-technical systems and general technology education. 
Table 1: Overview of the participants

\begin{tabular}{|c|c|c|}
\hline $\begin{array}{l}\text { Name } \\
\text { (not real) }\end{array}$ & Assigned system & Background \\
\hline Agatha & Sewage & Teacher in mathematics and science studies \\
\hline Bertram & Sewage & Teacher in mathematics and science studies \\
\hline Claude & Nuclear power & Teacher in crafts (wood and metal work) \\
\hline Dahlia & Internet & Teacher in mathematics and science studies \\
\hline Eustace & $\begin{array}{l}\text { Car } \\
\text { manufacturing }\end{array}$ & Teacher in mathematics and science studies \\
\hline Florence & $\begin{array}{l}\text { Car } \\
\text { manufacturing }\end{array}$ & $\begin{array}{l}\text { Teacher in mathematics and science studies, with a strong } \\
\text { interest in ICT. }\end{array}$ \\
\hline Gwladys & Sewage & Teacher in mathematics and social sciences \\
\hline Hildebrand & $\begin{array}{l}\text { Car } \\
\text { manufacturing }\end{array}$ & Teacher in mathematics and science studies \\
\hline Madeline & Nuclear power & Teacher in geography, science studies, and mathematics \\
\hline Roderick & Internet & Teacher in crafts (wood and metal work) \\
\hline Stephanie & Nuclear power & Teacher in mathematics and science studies \\
\hline Zenobia & Internet & Teacher in mathematics and science studies \\
\hline
\end{tabular}

As part of the course's examination, the students had to design some kind of learning activity, intended to teach their pupils about the assigned system or system type. The assignment was open ended, and the students could choose to develop a sequence of lessons, laboratory exercises, excursions or what they saw fit. This was described in a report that should include a plan of the major activities, intended learning outcomes, and routines for assessment. The design should be discussed and analysed using theoretical perspectives and literature used in the course. These reports provide the data for this study.

\section{Method}

The students' reports were read thoroughly and the following aspects were studied in particular:

- Which intended learning outcomes are included in the reports? What are the pupils supposed to know after the educational activities described in the reports?

- Which pedagogical tools and methods will be used (lectures, watching movies, visiting installations related to the systems, simulations, etc.) in the teaching activities?

- What types of assessment are planned? How does the teacher know whether the pupils have reached the intended learning outcomes at the end of the educational session?

- Does the approach to socio-technical systems vary with the teacher's educational background?

\section{Results}

\section{Intended learning outcomes}

The learning objectives described in the students' reports can be divided into three main categories:

A first category of learning objectives are those including knowledge and skills related to the system's components and technical function. Five sub-categories can be identified; those dealing with: (1) the concepts of the system, (2) the description of the system and its 
components, (3) the function of the system, (4) the borders of a system and/or how it interacts with surrounding systems, and (5) the vulnerability of the system. Typical examples of learning objectives in this category include 'the pupil should be able to describe what is meant by a "technical system" and provide a few examples.' (Bertram, sub-category 1), and 'describe the Internet as a system with its main components' (Roderick, sub-categories 1 and 2).

A second category consists of learning objectives related to knowledge and understanding of social and socio-technical aspects. This category also has five sub-categories, namely those related to: (1) how the system interacts with social and legal institutions, (2) the driving-forces for the development of the system at present, (3) historical development of the system, (4) gender issues related to the system, and (5) sustainability and environmental aspects. Typical intended learning outcomes in this category are 'each pupils should be able to describe how nuclear power has developed since the 1950s' (Claude, sub-category 3), and 'describe the driving forces for developing water purification technologies and sewage systems' (Bertram, sub-category 2).

The third category of learning objectives consists of those that are not specifically related to socio-technical systems, but deal with general skills. Since these are part of the technology syllabus, it can be relevant to train and examine them during a project about socio-technical systems. The examples found dealt with oral presentations, using digital tools (simulation programs, Powerpoint, and CAD programs), and writing technical reports.

The intended learning outcomes found in the students' reports about their planned teaching are listed in table 2. As the table shows, all students have included at least one learning objective in categories one and two - the systems' functions and components, and sociotechnical aspects respectively.

Four out of 12 students included an objective regarding the knowledge of the historical aspects of the development of technical systems and only two students mentioned the importance of gender issues in their learning objectives. Only 7 out of 12 students included a learning objective in where sustainability was mentioned or where vulnerability was discussed.

Table 2: Intended learning outcomes Theme

The systems' components and functions.

- concepts of the system Students (first name initials) Num.

- description of the system and its components

D, E, G, S 4

- function of the system

- borders of a system; interaction with other systems

- vulnerability of the system A, B, C, D, E, G, H, M, R 9 A, B, C, E, M, R, S, Z 8 A, E, F, H, M, R, S 7

A, B, C, D, E, M, Z 7

Socio-technical aspects

- interaction with society

A, B, D, E, F, G, H, M, R ,

- driving force/momentum

$\mathrm{S}, \mathrm{Z}$

- gender

A, , D, M, R, S, Z 7

- sustainability

- history, development over time

E, G

A, D, E, F, H, M, R

A, C, R, Z 
- using digital tools

- oral presentation skills

$\mathrm{R}$

- writing technical reports

$\mathrm{R}$

1

\section{Pedagogical methods}

The teaching activities and pedagogical methods suggested were all of traditional types. See table 3. Lecturing formed the basis of the teaching in ten of the reports. Simulation tools can provide good illustrations of how different components interact and how a minor disturbance in one part of the system can spread and affect the system as a whole. Ways of doing this, as well as examples had been shown during the course but only a few students chose to use it.

Table 3: Pedagogical methods and activities used when teaching about socio-technical systems

\begin{tabular}{lll}
\hline Method/activity & Students (first name initials) & Num. \\
\hline Lecturing & $\mathrm{B}, \mathrm{C}, \mathrm{D}, \mathrm{E}, \mathrm{F}, \mathrm{G}, \mathrm{H}, \mathrm{M}, \mathrm{R}, \mathrm{S}$ & 10 \\
Information search on the Internet & $\mathrm{A}, \mathrm{C}, \mathrm{D}, \mathrm{E}, \mathrm{M}, \mathrm{R}, \mathrm{S}, \mathrm{Z}$ & 8 \\
Debates and/or values exercises & $\mathrm{C}, \mathrm{D}, \mathrm{E}, \mathrm{F}, \mathrm{M}$ & 5 \\
Digital tools such as games, simulations, etc. & $\mathrm{B}, \mathrm{F}, \mathrm{H}, \mathrm{Z}$ & 4 \\
Field trips & $\mathrm{A}, \mathrm{B}, \mathrm{G}, \mathrm{H}$ & 4 \\
Writing technical reports & $\mathrm{A}, \mathrm{D}, \mathrm{R}$ & 3 \\
Experiments/laboratory exercises & $\mathrm{B}, \mathrm{H}$ & 2 \\
\hline
\end{tabular}

\section{Assessment}

It showed to be difficult to analyse the reports with respect to how students see themselves assess their pupils on the subject technical systems. All of them state that assessment shall take place, but a careful reading of the evaluation criteria showed that 8 out of 12 reports contained only the general assessment criteria stated by the National agency of education (Skolverket). These are intended for the contents of the technology subject as a whole, and not to be used for specific tasks or projects.

Four out of 12 students made their own assessment criteria based on their teaching activities, presented in the form of assessment matrices with varying degrees of detail.

Three students included activities only for formative assessment, i.e. activities mainly focused on how to improve teaching and learning throughout the project by giving feedback to the pupils. Three students included both formative and summative processes and six students planned to use only summative assessment activities.

\section{Analysis and discussion}

Socio-technical systems were first introduced in the technology subject in compulsory school in Sweden in the curriculum of 1994. It was strengthened in the next curriculum, published in 2011. It provides teachers with unique opportunities to help pupils to understand technology at large - as a part of society, formed by society, and forming society - instead of as individual artefacts. Unfortunately, systems have seldom been emphasized in teacher education or in textbooks. ${ }^{10,11}$ To make things worse, many teachers lack training in technology education and textbooks are seldom used. ${ }^{9}$ Including a module dedicated to sociotechnical systems and how to plan education around them was an attempt to remedy this, to provide the teachers who attended with the knowledge and skills necessary to make pupils understand how technologies interact with each other, with institutions, individuals, and 
organisations. After analysing the students' reports, we must conclude that we have had partial success, but that there is room for improvement.

Socio-technical systems form an abstract concept, which is inherently difficult to grasp and interpret. The system itself is an analytical unit; a nuclear power plant can be regarded as a quite complicated technical system in itself, but it can also be a component in a larger system, supporting a large region with electricity. What is transferred in a system is also ambiguous in some cases. From an end user's point of view the Internet is an information system, whereas the technicians who build its physical infrastructure regard it as a system of electrical wires and optical fibres. How to make pupils understand this is not easy; many teenagers want clear answers and are reluctant to accept a teacher's 'it depends ...'. This causes potential problems for a teacher who wants to explicitly teach pupils about socio-technical systems and be outspoken about this. But it is of course possible to teach about a sewage system without using any of the terms used in the STS literature, and describe the system's components and functions without referring to 'black boxes' and redundancy.

All students had participated in the same teaching activities concerning socio-technical systems and read the same books and articles. In spite of that, how they chose to present the systems to their own pupils varied considerably. Some of them want to explicitly deal with systems, using STS terminology (e.g. Hildebrand, who included the use of STS terms in his intended learning outcomes), while others prefer to describe it as technology in a wider context (e.g. Florence, who discusses systems with a minimum of system-specific terms). From the perspective of technological literacy - how to enable the pupils to 'orient themselves and act in a technologically intensive world' as Skolverket puts it in the introduction to the technology syllabus ${ }^{2}$ - it really does not matter which terms that are used. If on the other hand, we want to prepare the pupils for further studies of socio-technical systems, the STS terms should be preferable. One of the core abilities stated in the technology syllabus is to be able to use the concepts and expressions of technology, ${ }^{2}$ whether this includes the STS terms is a matter of interpretation.

The suggested teaching activities are surprisingly traditional. As socio-technical systems really are suitable for interdisciplinary studies, it would have been possible for the students to describe work where different school subjects collaborated. For example, in the curriculum it is stated that energy in general and electricity production in particular should be included in the physics subject, and that environmental aspects of energy production should be studied in civics. $^{2}$ Therefore, when studying nuclear power plants, it would be possible to create a project that involves more subjects than technology, and give pupils and teachers opportunities to explore many different aspects of this particular way to generate electricity. Similar opportunities, but not stated as explicitly, exists for the other system types. Only one of the students explicitly discusses collaboration between subjects at length, and that is Madeline, one of the teachers with a background in the social sciences. Madeline and Gwladys, the two social-science teachers, are also those who have included the most elaborate exercises regarding ethics and politics. This is taught in the form of debates and discussions, where normative assertions are measured against each other. For the teachers without schooling in the social sciences, it may be difficult to see how social and political aspects can be made relevant in the technology subject, even though this had repeatedly been discussed during seminars and described in the course's literature.

The projects described by the students deviate from traditional Swedish technology teaching in one important way: constructing and building plays only a minor part here, while it 
dominates the technology subject at large. ${ }^{9}$ Judging from the syllabus text, technology need not be a subject based on construction and design, and to work with socio-technical systems, which forces the teachers to take social and political issues under consideration can serve as a good example of a different approach to technology teaching.

To assess pupils' achievements and knowledge, some kind of goal or intended outcome is necessary. Without knowing where you are heading, it is impossible to know whether you have come there or not. Therefore, well designed learning objectives or intended learning outcomes are a necessity for both formative and summative assessment. In the students' reports, the intended learning outcomes are seldom well designed. Some of them are not even really possible to evaluate. One example is Hildebrand's 'pupils should know that a lorry is a part of a transportation system.' Knowledge cannot be evaluated, other than indirectly. We cannot study knowledge, only signs of knowledge expressed through various actions.

Therefore, it is clearer if the actions are described, actions that can be observed and evaluated. It is obviously very difficult to formulate learning outcomes that could serve as a basis for criteria for assessment; most likely because the teachers are not used to think about systems as one area of study or a closely connected cluster, but rather as a disparate collection of concept from the social sciences, the natural sciences, and engineering. To encourage this view and systemic understanding proved more difficult than expected. To encourage this view and systemic understanding proved more difficult than expected.

It was also seen that the students found it difficult to include a holistic approach to this area as few learning objectives included terms related to gender issues, historical aspects or even sustainability. These are factors that should permeate all teaching. Our conclusion is that a deeper understanding about technological systems, providing a greater self-confidence by the students, is needed before the holistic view can be taken into the teaching.

This paper has discussed how the authors' students - experienced teachers in the midst of a professional development course in technology - describe possible ways to teach about sociotechnical systems in Swedish compulsory school. Therefore, it is unavoidable that the discussion partly deals with the results of the course and its shortcomings. However, we strongly believe that some of the results are generalizable to a larger group of teachers. The study of socio-technical systems is an area that is inherently interdisciplinary. It is therefore difficult to study in a school system where reality is divided into subjects, partly on arbitrary grounds. At the same time, it could serve to unite subjects - to highlight the fact that different aspects of reality actually affect each other even though they belong to different subjects in school. This is obviously hard, as teacher education as well as compulsory school is divided into subjects and to break these structures a different way of thinking and organising work is necessary. Education of technology teachers is a beginning, but to fully embrace the concept of socio-technical systems in school, education of other teachers and heads of schools would also be necessary. We believe that this would strengthen the pupils' technological literacy, and be well worth the effort. The first step is a stronger community of engineering and technology teachers, versed in engineering as well as science and technology studies.

\section{Bibliographic information}

1. Lövheim, D. (2013). Teknikens gränser - Formering och positionering av grundskolans teknikämne 1975-2010 [The limits of technology: Forming and positioning the technology subject in compulsory school 1975-2010]. In: Hallström, J., Hultén, M. \& Lövheim, D. (eds) Teknik som kunskapsinnehåll i svensk skola 1842-2010 [Technology 
as subject contents in Swedish schools 1842-2010], pp. 215-250. Möklinta, Sweden: Gidlunds förlag.

2. Skolverket (2011a). Curriculum for the Compulsory School, Preschool Class and the Recreation Centre 2011. URL http://www.skolverket.se/publikationer?id=2687, accessed 3 December 2013. Stockholm: Skolverket [The Swedish National Agency for Education].

3. Skolverket (2011b). Kommentarmaterial till kursplanen i teknik [Comments to the Syllabus in Technology]. URL http://www.skolverket.se/publikationer?id=2568, accessed 3 December 2013. Stockholm: Skolverket [The Swedish National Agency for Education].

4 Hughes, T. P. (1989). The System Must Be First. In: American Genesis pp. 184-248. New York: Viking Penguin.

5 Joerges, B. (1988). Large technical systems: Concepts and issues. In: Mayntz, R. \& T. P. Hughes (eds) The Development of Large Technical Systems, pp. 9-36. Boulder, CO: Westview Press.

6 Kroes, P. (2012). Technical Artefacts: Creations of Mind and Matter. Dordrecht, The Netherlands: Springer.

7 Gyberg, P. \& Palm, J. (2009). Avbrott i vardagen [Everyday interruptions]. In: Gyberg, P. \& Hallström, J. (eds) Världens gång - teknikens utveckling [The passage of time and the development of technology], pp. 221-234. Lund, Sweden: Studentlitteratur.

8 Perrow, C. (1999/1984). Normal Accidents: Living With High-Risk Technologies. Princeton, NJ: Princeton University Press.

9 Skolinspektionen (2014). Teknik - Gör det osynliga synligt [Technology: Make the Invisible Visible]. URL http://www.skolinspektionen.se/Documents/Kvalitetsgranskning/teknik/kvalgr-teknikslutrapport.pdf, accessed 13 February 2015. Stockholm: Skolinspektionen [The Swedish School Inspectorate].

10 Klasander, C. (2010). Talet om tekniska system [Speaking of Technical Systems]. Doctoral dissertation from Linköping University, Sweden.

11 Svensson, M. (2011). Att urskilja tekniska system - Didaktiska dimensioner $i$ grundskolan [Distinguishing Technical Systems: Pedagogical Dimensions in Compulsory School]. Doctoral dissertation from Linköping University, Sweden. 